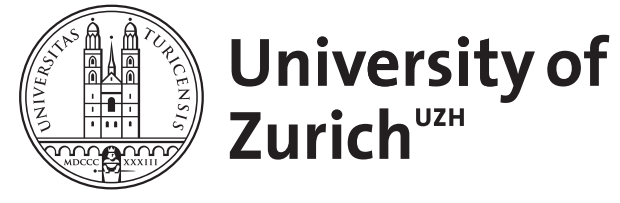

\title{
The quality of schwa in Swiss German
}

\author{
Hove, Ingrid
}

\begin{abstract}
Observations in specialist literature as well as the perception of lay people suggest that in Swiss German dialects in general and even more so in the dialects of Central Switzerland the unaccented vowel in words such as machä ('make'), which is here referred to as schwa, is not a completely central vowel corresponding to [ə] but is closer to [æ] or []. In order to verify whether these observations are correct, recordings from Central Switzerland and Zurich were analyzed and later also compared to recordings of speakers from Germany speaking Standard German. The results show that speakers of both Swiss German dialects pronounce schwa with a more open quality than the speakers from Germany. The analyses of different factors reveal that for the Swiss but not for the Germans the degree of openness of schwa correlates with a more deliberate articulation. It can, therefore, be assumed that the Swiss German schwa's target is not a completely central but rather a slightly open vowel. Furthermore, in the dialects of Central Switzerland the vowel is articulated with more spread lips than in Zurich German. Nevertheless, the formant values lead to the conclusion that the Swiss German schwa is still fairly central and does not overlap with any front vowels. It is most precisely represented by the phonetic symbol [].
\end{abstract}

DOI: https://doi.org/10.25162/zdl-2020-0001

Other titles: Die Vokalqualität von Schwa im Schweizerdeutschen

Posted at the Zurich Open Repository and Archive, University of Zurich ZORA URL: https://doi.org/10.5167/uzh-189378

Journal Article

Published Version

Originally published at:

Hove, Ingrid (2020). The quality of schwa in Swiss German. Zeitschrift für Dialektologie und Linguistik, 87(1):3-24.

DOI: https://doi.org/10.25162/zdl-2020-0001 


\section{INGRID HOVE}

\section{The quality of schwa in Swiss German}

\section{Die Vokalqualität von Schwa im Schweizerdeutschen}

ABSTRACT: Observations in specialist literature as well as the perception of lay people suggest that in Swiss German dialects in general and even more so in the dialects of Central Switzerland the unaccented vowel in words such as mach $\underline{\ddot{a}}$ ('make'), which is here referred to as schwa, is not a completely central vowel corresponding to [ə] but is closer to [æ] or $[\varepsilon]$.

In order to verify whether these observations are correct, recordings from Central Switzerland and Zurich were analyzed and later also compared to recordings of speakers from Germany speaking Standard German. The results show that speakers of both Swiss German dialects pronounce schwa with a more open quality than the speakers from Germany. The analyses of different factors reveal that for the Swiss but not for the Germans the degree of openness of schwa correlates with a more deliberate articulation. It can, therefore, be assumed that the Swiss German schwa's target is not a completely central but rather a slightly open vowel. Furthermore, in the dialects of Central Switzerland the vowel is articulated with more spread lips than in Zurich German. Nevertheless, the formant values lead to the conclusion that the Swiss German schwa is still fairly central and does not overlap with any front vowels. It is most precisely represented by the phonetic symbol [3].

Keywords: Schwa, Vowel quality, Swiss German, Pronunciation, Perception, Transliteration

KURZFASSUNG: Beobachtungen in der Fachliteratur sowie in der Wahrnehmung von Laien deuten darauf hin, dass der hier als Schwa bezeichnete unbetonte Vokal in Wörtern wie machä ('machen') in Dialekten der Deutschschweiz im Allgemeinen und der Zentralschweiz im Speziellen nicht völlig zentral ([ə]) ist, sondern näher bei $[æ]$ oder $[\varepsilon]$ liegt.

Um zu überprüfen, ob diese Beobachtungen zutreffen, wurden Aufnahmen aus der Zentralschweiz und Zürich analysiert und später noch mit Aufnahmen von Standarddeutsch sprechenden Deutschen verglichen. Die Ergebnisse zeigen, dass die Schweizer Dialektsprecher Schwa mit einer offeneren Qualität aussprechen als die Deutschen. Die Analysen verschiedener Faktoren zeigen, dass für die Schweizer, nicht aber für die Deutschen, der Grad der Offenheit von Schwa mit einer bewussteren Artikulanorreliert. Es kann daher angenommen werden, dass das Target des Schwa im Schy ckerdeu the N völlig zentraler, sondern ein leicht offener Vokal ist. Zudem wird der V kal in Dial kten a $r$ Zentralschweiz mit gespreizteren Lippen artikuliert als im Zürichd ats hen env thässt ich aus den Formantenwerten schliessen, dass Schwa im Schweizerc eutso imy or no eir eher zentraler Vokal ist, bei dem kaum 
Überschneidungen mit den vorderen Vokalen auftreten. Der Laut wird am genauesten durch das phonetische Symbol [3] wiedergegeben.

Schlagworte: Schwa, Vokalqualität, Schweizerdeutsch, Aussprache, Wahrnehmung, Verschriftung

\section{Introduction}

The quality of the different vowels varies from one Swiss German dialect to another. This is a fact of which the speakers are highly aware and which is well documented in dialectological publications (for example HOTZENKÖCHERLE 1962: volume I). However, both in lay people's awareness as well as in research the focus lies on full vowels in accented syllables whereas little attention is paid to the generally unaccented central vowel schwa.

There is reason to believe that there are differences in the quality of schwa between different dialects spoken in Switzerland on the one hand and between Swiss German dialects and Standard German as spoken in Germany on the other hand. These assumptions are based on the following observations:

- There are a few observations in specialized literature on Swiss German which indicate that the quality of the vowel in the ending of infinite verbs is more open in the dialects of Central Switzerland than in other regions (HOTZEN KÖCHERLE 1975: volume III: map 1, WEBER 1987: 29; both based upon auditory perception). Furthermore, for Standard German it has been stated that in varieties in the southern part of the German-speaking area the vowel in unstressed syllables with $<\mathrm{e}>$ is not pronounced as centrally as in Central and Northern Germany (KLEINER/KNÖBL/ MANGOLD 2015, KRECH et al. 2009, CHRISTEN et al. 2010). These findings will be reviewed in section $\mathbf{1 . 2}$.

- As far as lay people are concerned it can be observed that when writing informal short messages in their dialect, many native speakers of Swiss German tend to use the letter $<$ ä $>$ for sounds which are here defined as schwa (see section 1.1). This could indicate that they are reluctant to associate the dialectal vowel with the Standard German schwa.

The aim of the present study is to examine the perceived and the acoustic quality of schwa. After a discussion of the status of schwa in Swiss German and in Standard German (section 1) the linguistic and metalinguistic data from Central Switzerland and Zurich is presented (section 2). The metalinguistic comments of the informants from Central Switzerland as well as a corpus of text messages are analyzed in order to find out about the speakers' perception of schworaction 3 ). The linguistic data is used for acoustic analyses examining the prece quali of wa in Central Swiss German and in Zurich German in order to fin out he it is a central vowel or a vowel clos-

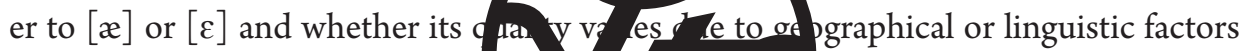
(section 4). Furthermore, the qua ity hy $\mathrm{nn}^{\mathrm{S}}$ iss ferman is compared to that in northern Standard German (sectio 


\subsection{Definition of schwa}

In the present study, the term "schwa" is used to designate the vowel which occurs in lexically unstressed syllables of verbs, nouns and adjectives as well as in articles (singä 'sing', $\underline{a ̈}$ Tanä 'a pine tree', $\underline{a} n$ chliinär $\underline{a}$ Wagä 'a smaller wagon') in most Swiss German dialects (see next section). In Standard German, schwa refers to the lexically unstressed vowel spelled with <e> (for example ich singe 'I sing', eine Tanne 'a pine tree', bekommen 'get').

Both in Swiss German and in Standard German, schwa can occur in word final and medial position in words also containing at least one full vowel. In Swiss German schwa can also be in the word initial position in articles such as än or äs; in Standard German initial schwa only occurs in weak forms of articles such as en or em. Furthermore, in Swiss German schwa can be the second part of a diphthong (niä 'never', guät 'good').

In Standard German, the central vowel [e] appears in unstressed syllables or diphthongs involving <r> (Vater ['fa:te] 'father', nur [nu:e] 'only'), whereas in most Swiss German dialects this vowel does not occur.

The phonological status of schwa in Standard German is contested. There are arguments which speak in favor of a phonemic status of schwa - most importantly the existence of minimal pairs such as Freunden ([-ən] 'friends') vs. Freundin ([-In] 'girlfriend') or Liebe ([-ə] 'love') vs. lieber ([-e] 'nicer'). Arguments against its phonemic status are its restricted distribution and the schwa/zero alternation in word pairs such as TüreTür ('door') (see WIESE 1986, NOSKE 1992: 141-183, STAFFELDT 2010).

In the Swiss German dialects of Central Switzerland and Zurich (see FLEISCHER/ SCHMID 2006: 247) schwa can be considered as a phoneme because of minimal pairs such as the following:
(1) liäbä 'to love'
vs. Liäbi 'love'
(2) än rand 'an edge'
vs. an rand 'towards the edge'
vs. in rand 'into the edge'

(3) än guätä Maa 'a good man' vs. ä guäti Frau 'a good woman'

This interpretation is strengthened by the observations that in Swiss German schwa can be the only vowel in a word (for example in the definite article dä or in the indefinite articles $\ddot{a}$ or $\ddot{a} n$ ) and that there is no systematic alternation between schwa and zero (for example Tanä, Wagä but not *Tan, *Wag). The term "schwa" in this paper thus refers to the phoneme /ə/. Whether this phoneme is pronounced with a sound that corresponds to the central vowel $[\partial]$ or with a different vowel is the object of investigation.

\subsection{Schwa in Swiss German and in Standand German}

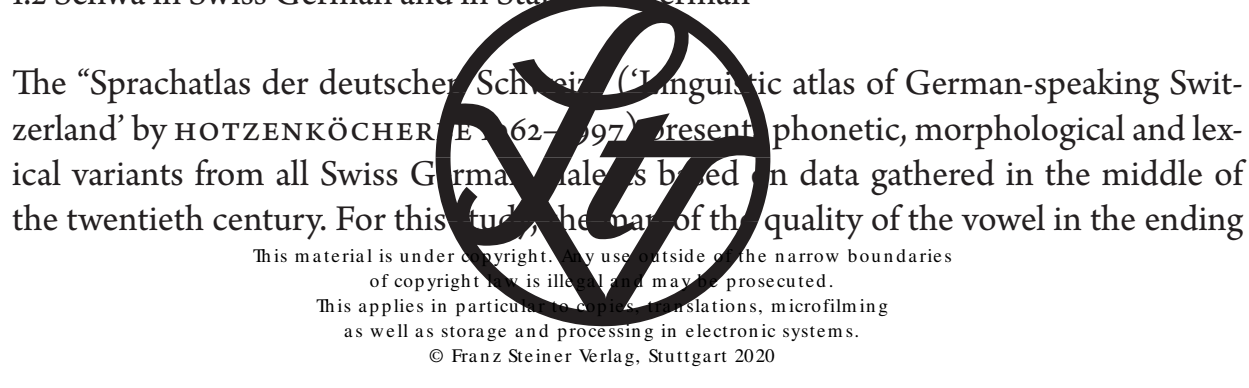


of infinite verbs (HOTZENKÖCHERLE 1975: volume III: map 1) carries highly relevant information (see figure 1). It shows that in the dialects of Central Switzerland the vowel in this position is pronounced with a more open quality (towards $[æ],[\varepsilon]$ or $[\mathrm{a}]$ ) than in the dialects of most of German-speaking Switzerland. The two dialects of Valais and Grisons are not considered here due to their verb endings with full vowels.

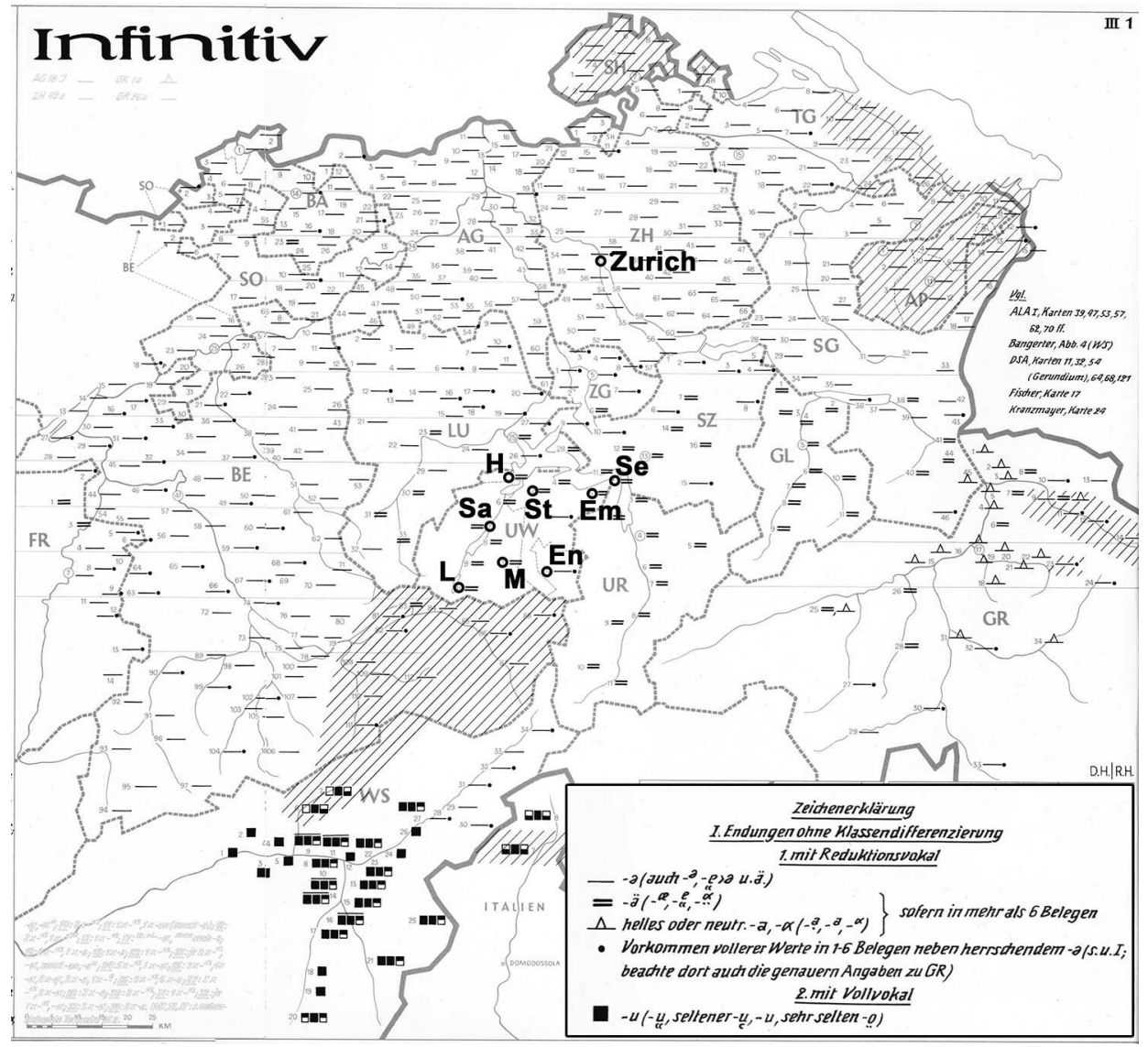

Fig. 1: Map from the "Sprachatlas der deutschen Schweiz" (HOTZENKö CHERLE 1975: volume III: map 1) showing the quality of the vowel in the ending of infinite verbs.

The towns the informants of Central Switzerland come from are marked with the first letter(s): Hergiswil (H), Stans (St), Emmetten (Em), Sarnen (Sa), Lungern (L), Melchtal (M), Engelberg (En) and Seelisberg (Se); the speakers of Zurich German come from the area around Zurich.

A very similar distribution can be se $n$ on th mo the "Sprachatlas der deutschen Schweiz" showing the pronunciati n on hrocen ring diphthongs deriving from Middle High German ie, uo and ü (n exa Iple 1 viär ' ur', Fuäss 'foot', Stüäl 'chairs'): the second part of these diphthor $\mathrm{gs}$ is $\mathrm{Car}^{\prime} \mathrm{d}$ as $\left.æ\right] \mathrm{pr}$ the dialects of Central Switzerland, for the other dialects (ap tf th ais) is indicated as [o] (HOTZEN- 
KÖCHERLE 1962: volume I: maps 140-145). The diphthongs are, however, not included in the acoustic analyses of the present study.

For the dialect of the canton of Nidwalden, in which seven of the eight towns of the corpus of Central Switzerland are located, NIEDERBERGER describes the $e$-sound in unaccentuated syllables as a "short, slightly open E between E and $\ddot{A}$ " (NIEDERBERGER 2007: 16; translated by the author). In his dictionary he transcribes it with the same letter $(<\grave{e}>)$ he uses for the stressed vowel $[\varepsilon]$, for example $<$ Èrgèr $>$ ('nuisance') or $<$ nèrggèlè> ('to nag') (NIEDERBERGER 2007: 16).

In his grammatical description of Zurich German, WEBER (1987: 29) writes that the "e" in unaccented syllables is a reduced neutral sound but he specifies: "Er hat eher ä- als ö-Klang. In der ländlichen Sprechweise, bes. gegen das [Zürcher] Oberland hin und hier selber nimmt er etwas bestimmtere ä-Farbe an, doch nicht so ausgeprägt wie in den Glarner oder Schwyzer Mundarten." ('It sounds more like an ä than like an ö. In the rural dialects, especially towards and in the [Zurich] Oberland it has more of an ä-color but not as pronounced as in the dialects of Glarus or Schwyz.')

With regard to Standard German, the two main pronunciation dictionaries state that in Southern Germany, Austria and Switzerland the pronunciation of schwa is less central than in Central and Northern Germany: In the "Duden" (KLEINER/KNÖBL/MANGOLD 2015: 72) the "southern schwa" is described as being between [e] and $[\varepsilon]$, often closer to $[\varepsilon]$, and transcribed with the symbol [3]; in the "Deutsches Aussprachewörterbuch" (KRECH et al. 2009: 246 and 268) it is described as front vowel which is only slightly centralized in Austrian Standard German and in Swiss Standard German (for Austria see also BÜRKLE 1995: 100, MOOSMÜLLER 2007: 52; for Switzerland see also HOVE 2002: 119, CHRISTEN et al. 2010: 190-192).

It can be mentioned here that open pronunciations are also observed in the area of Hamburg. The pronunciation of $[\varepsilon]$ in the place of a final schwa in words such as Stube ('living room') or Wolke ('cloud') is listed in the "Hamburger Variablenkatalog" ('Hamburg Catalogue of Variables' by BIEBERSTEDT/RUGE/SCHRÖDER 2016: 404). The "Norddeutscher Sprachatlas" ('Linguistic Atlas of Northern Germany' by ELMENTALER/ROSENBERG 2015: 173-178) as well as LAMELI (2004: 229) also note this pronunciation variant for Standard German [e]. This open pronunciation is sometimes reflected in the written language by the letter $<\ddot{a}>$ when imitating the Hamburg pronunciation, for example in the spelling < biddä > (for < bitte > 'please'/'there you go', for example in the title of a movie episode of the television series "Dittsche" featuring a Hamburg milieu figure (WDR 2010) or in a newspaper column about life in Hamburg (sOKOLOWSKY 2012)).

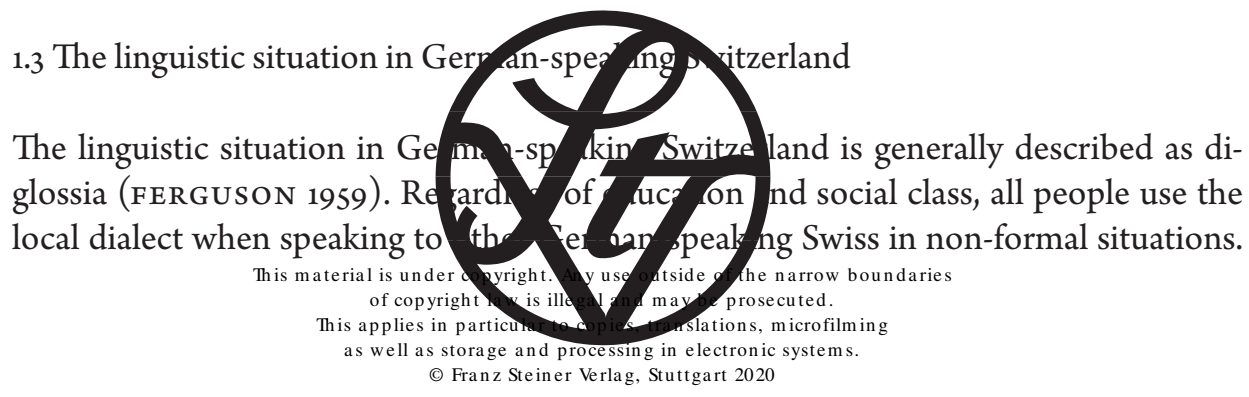


Standard German is only spoken in formal situations such as in education or in politics as well as with non-dialect speakers. In written language Standard German is used. The dialect is only written rarely in short informal communication such as text messages. There is no binding orthography and the rules for Standard German spelling can only partly be applied to Swiss German.

While the older literature on diglossia describes the dialect as the form with low prestige, it is now acknowledged that in linguistically stable areas such as German-speaking Switzerland the dialect has a high prestige in many situations. Most Swiss are proud of their dialect, which they see as a cultural asset. On the one hand, a person's dialect displays subtle differences to dialects of other areas of Switzerland; on the other hand, the Swiss German dialects as a whole set German-speaking Switzerland apart from Germany and Austria - less by its linguistic variants than by its use as the everyday language of German speaking Swiss of all social classes. The dialect thereby serves both as local and as national identifier. This has the effect that when people participate in a linguistic study, they do not converge to Standard German but rather tend to diverge by using obsolete variants.

\section{Data}

\subsection{Data from Central Switzerland}

The data from Central Switzerland comes from the "Ländere ${ }^{\mathrm{n}}$ " project, which examines Central Switzerland both as a linguistic and as a perceptual space (CHRISTEN/BUCHELI/GUNTERN 2015, CHRISTEN 2015). The data contains recordings of informants from eight different towns in Central Switzerland, namely Hergiswil, Stans, Emmetten, Sarnen, Lungern, Melchtal, Engelberg and Seelisberg (see map in fig. 1).

For the present study both linguistic and metalinguistic data were used. In order to find out about lay people's perception of schwa, the parts of the interviews in which the informants describe their own dialect and other Swiss German dialects were studied. These were analyzed for all 60 informants.

For the phonetic analyses the recordings of five informants in each of the eight towns were chosen (the five additional recordings in four of the towns were omitted), thus amounting to a total of 40 recordings. The 17 women and 23 men were between 40 and 60 years old at the time of the data collection. All recordings were made at the homes of the informants in a quiet room using a $\mathrm{Zoom} \mathrm{H}_{2}$ recording device.

The 17 occurrences of schwa were taken from six sentences used by GEORG WENKER for the "Sprachatlas des Deutschen Reiche" ('Linguistic atlas of Germany' 1888-1923; published by SCHMIDT/HERRGEN 0 o1ff.) he potences were written in Standard German, the informants were asked to the et em in o their dialect. The fact that this involves translation from one var en into not er varis y of the same language is not ideal but since the Swiss dialects a e ha " wr" en "ees ction 1.3) this procedure is not more unnatural than presenting th so no $\mathrm{cten} h$ Swiss German, which is why 
this method is commonly used in dialectological studies. For every sentence, the transcriptions were segmented and aligned to the recordings using WebMAUS with forced alignment (KISLER/SCHIEL/SLOETJES 2012, WebMAUS 2015). The segmentation was then corrected manually.

In total, the tokens which could be used for the study amounted to 530 tokens for schwa and 585 tokens for the front unrounded and back rounded vowels $(/ \mathrm{i} /, / \mathrm{e} /, \mathrm{l} /$, $/ \mathrm{a} /, / \mathrm{o} / \mathrm{and} / \mathrm{u} /$, since $/ \varepsilon /$ does not normally occur in the Central Swiss dialects). ${ }^{\text {T The }}$ full vowels were used on the one hand for the normalization process of the formants (see section 2.3), on the other hand for judging the position of schwa in relation to these vowels.

\subsection{Data from Zurich}

The data from Zurich consists of recordings made within the research program "Language and Space" (<https://www.spur.uzh.ch/en.html>; see for example RUCH 2015). The speakers are 16 women from the Zurich area who were at the time of the recording between 18 and 24 years old. All participants were monolingual native speakers of Swiss German and self-reported speakers of the Zurich dialect who grew up in the Zurich area. Most of them were students at one of the universities or technical colleges in the region of Zurich (RUCH 2015).

Every speaker translated five sentences from Standard German to Zurich German and pronounced 15 single words prompted by picture cards. This amounts to 370 tokens for schwa and 289 tokens for full vowels $(/ \mathrm{i} /, / \mathrm{e} /, / \varepsilon /, / \mathfrak{x} /, / \mathrm{a} /$ and $/ \mathrm{o} /$, since $/ \mathrm{u} /$, unfortunately, does not occur in the Zurich corpus). The recordings were carried out, transcribed and segmented by HANNA RUCH. While the translation task is basically the same as for Central Switzerland, the influence of the difference of the method of data collection in which individual words are elicited is examined in section 4.2.

2.3 Processing of the data and vowel normalization

For all vowels the first three formants, the duration and the intensity were extracted using a Praat (BOERSMA/WEENINK 2015) script. The maximal number of formants to be extracted was set to five. For female speakers the maximum value was set to $5500 \mathrm{~Hz}$, for male speakers to $5000 \mathrm{~Hz}$. For each of the formants the median, mean, and standard deviation were calculated over the whole duration of the segment. It was decided to

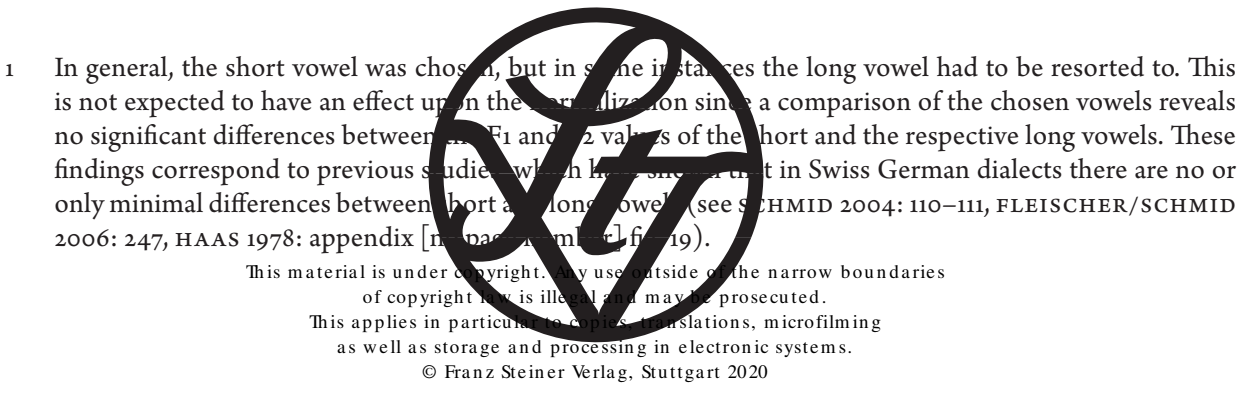


use the median as a basis for the present analyses since it is more robust against faulty assignments and since it minimizes the effects of formant transitions. Values diverging by more than three standard deviations were removed.

In order to eliminate variation caused by physiological differences among speakers while at the same time preserving sociolinguistic, dialectal, and cross-linguistic differences in vowel quality, the vowels were normalized. This was especially necessary in this case, since the corpus from Central Switzerland contains both female and male speakers while the corpus from Zurich only contains female speakers. The normalization eliminates the differences due to differences in the vocal tract to a large extent. A test comparing the normalized formants of the female and male speakers of the corpus of Central Switzerland revealed very similar values for the two groups, thus showing that the procedure was effective.

The normalization was done using the online platform NORM, version 1.1, by THOMAS and KENDALL (2007). The platform allows the user to choose the method with which to perform the normalization and then does the calculation based on a table containing the vowel, the identity of the speaker, the context and the values for $F_{1}, F_{2}$ and $\mathrm{F}_{3}$, which in this case had been previously extracted using Praat (BOERSMA/WEENINK 2015). Since the set of vowels was not identical for the Central Switzerland and the Zurich corpus, both a formant intrinsic normalization method using only the data of schwa as well as a formant extrinsic normalization method using the information across all vowels were applied. In both cases the method developed by NEAREY (1977) was chosen since studies comparing different normalization methods found this method to perform well (ADANK/SMITS/VAN HOUT 2004, FLYNN 2011) and since it also includes the third formant.

The results of the normalized formant values of schwa of the two procedures were very similar. Therefore, for the further analyses the values of the formant extrinsic normalization procedure were used. The information on the full vowels was useful for determining the position of schwa in relation to the front and back vowels. Furthermore, vowel-extrinsic methods are generally considered to perform better than vowel-intrinsic methods (ADANK/SMITS/VAN HOUT 2004, FLYNN 2011).

\section{Speakers' perception of schwa}

\subsection{Informants' mentions of schwa}

In the interviews within the "Ländere" project (see section 2.1) both linguistic and metalinguistic data were collected. The infamants were asked to list characteristics of their own and other Swiss German di ects. A tal pl lmost 400 statements referring to phonetic characteristics were gath red. hav city of these observations by lay people - for example on the geograpl ra dist but hof th variant [ui] - are surprisingly accurate. However, only one state hent fich orr por ds to $0.25 \%$ of all meta-linguistic phonetic comments, refers to (e rowe an informant from Hergiswil 
states that people from Lungern and the neighboring town Giswil speak "with ä” and gives hüorä (intensifier) and heuwä ('make hay') as examples.

One of the reasons why the pronunciation of schwa is referred to so rarely most likely has to do with the fact that schwa neither has a letter of its own in the German alphabet nor a name in everyday language. Using the terminology proposed by AUER (2014), schwa can be considered as not salient in a sociolinguistic sense but perhaps as salient in a cognitive sense since the way in which dialect speakers transliterate the sound indicates that they do perceive a difference between their own vowel and Standard German schwa (see also LENZ 2010).

\subsection{Transliteration of schwa in Swiss German text messages}

Though the Swiss German dialects are primarily used in oral communication, there are situations in which the dialect is also used in writing. Typically, these are short informal texts such as mobile phone text messages. Because there are no binding orthographic rules, people are forced to choose their own spelling (see SIEBENHAAR 2006, CHRIsTEN 2004). In doing so, writers apply different, partially conflicting strategies:

- The spelling aims at reflecting the pronunciation.

- The spelling is influenced by the orthography of Standard German.

- The spelling deliberately diverges from Standard German orthography in order to mark the message as dialectal.

- The variant helps avoid ambiguity, for example <iä> (see below).

- The writer wants to be fast and/or original by using short variants ( $<$ thx $>$ 'thanks'), acronyms (<LOL $>$ 'laugh out loud') or abbreviations containing numerals $(<2>$ for 'two'/'to'/'too'; <18> 'late') or single letters (<c u> 'see you') (see CRYSTAL 2008, GRANT 2013).

In order to find out more about the spelling variants used for schwa, a query was undertaken using the Swiss SMS Corpus (STARK/UEBERWASSER/RUEF 2009-2014), which contains a total of 25947 text messages of which 10706 are written in Swiss German. Since for most text messages no demographic information is available, the messages were not filtered by dialect.

The study of these text messages reveals that many writers use both $<\mathrm{e}>$ and $<\ddot{a}>$ to represent the sound here referred to as schwa. Due to the little amount of text available from most writers it is difficult to analyze how consistent they are. There seem to be some writers who tend to use $<\mathrm{e}>$ whereas no writer of whom the corpus contains at least four text messages consistently usa $>$ Most writers vary between $<\mathrm{e}>$ and $<\ddot{a}>$. This can be illustrated by two exa ples fro a th wiss SMS Corpus:

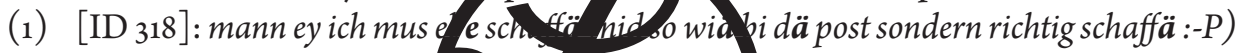
('man, I have to work [no in at e porfoffice - real work]').

(2) [ID: 452]: Guätä schöne big h ho h hä hä guätä tag gha? Jep da isch supi mit next mittwuch, warte am h hi bre $\mathrm{n}$ tre punkt=) freu mi rießig, schös erhol- 
sams öbetli wünsche $i$ ('Good evening love, I hope you had a good day? Yes it is super for next Wednesday, I will wait at 3:30 for you at the meeting point =) I am very excited, I wish you a nice relaxing evening')

In a similar study, SIEBENHAAR (2006: 27) analyzes the spelling of the infinitive of the word chatten ('chat'). In local chat rooms of Bern and Zurich between $24 \%$ and $29 \%$ of the occurrences of this word (about 400 tokens in each chat room) were spelled with a final $<\ddot{a}>$, most other occurrences with a final $<$ e $>$. The spelling variant $<$ ä $>$ is also observed in business or product names; PETKOvA (2017) lists examples such as a florist named Bluämä-eggä (literally 'flower corner') or a bakery product advertised as Bürä-Biräwegge ('farmer's pear bread').

CHRISTEN (2004: 79-80) interprets these spelling variants as a strategy of visually marking the text as dialect by diverging from Standard German orthography, thus serving as a kind of reading aid. Another function of the spelling variant $<\ddot{a}>$ is disambiguation: while <ie > can stand for either [iə] when based on phonetic spelling (as in lieb in example 2) or [i:] when based on Standard German orthography (as in rießig in example 2), the spelling <iä> as in the above wiä clearly represents the diphthong.

The question arises, though, whether the spelling variant $<\ddot{a}>$ does not also indicate a certain awareness of a different quality of schwa - namely in comparison to its pronunciation in Germany - in the sense that the Swiss German vowel is perceived as closer in quality to $[æ]$ or $[\varepsilon]$ than to the Standard German [ə]. This assumption is supported by the observation that when transcribing phonetically, many students use $[æ]$ or $[\varepsilon]$ for the unstressed vowels of their own dialect, insisting that the sound is closer in quality to the front vowel in question than to a central schwa.

\section{Results of the acoustic analyses}

\subsection{Overview of the vowel quality}

The following ellipses created in Praat based on the normalized F1 and F2 values of all vowels with one standard deviation present an overview of the position of schwa in the vowel space of the speakers from Central Switzerland and from Zurich.

Figures 2 and 3 show that in the dialects of Central Switzerland and Zurich the majority of the pronunciations of the vowels here defined as schwa are central vowels with $\mathrm{F}_{1}$ values higher than those of /i/ and lower than those of /æ/ and $\mathrm{F}_{2}$ values between those of /e/ and /o/. The values for schwa are quite dispersed, especially for the first formant.

As for the other vowels, for both alects $1 \mathrm{~m}$ and central position of $/ \mathfrak{x} /$ is remarkable, as well as the fact that in ne d. hese arts of Switzerland / $a /$ is clearly a back vowel. 


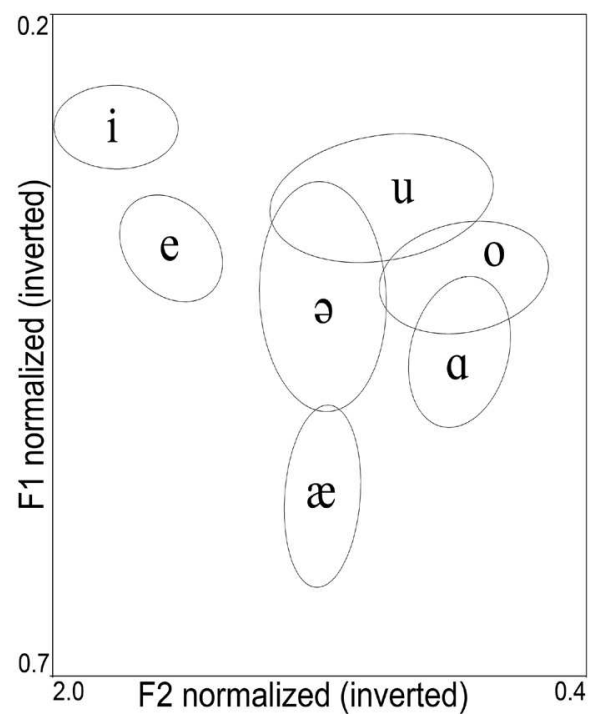

Fig. 2: Normalized vowels of speakers from Central Switzerland

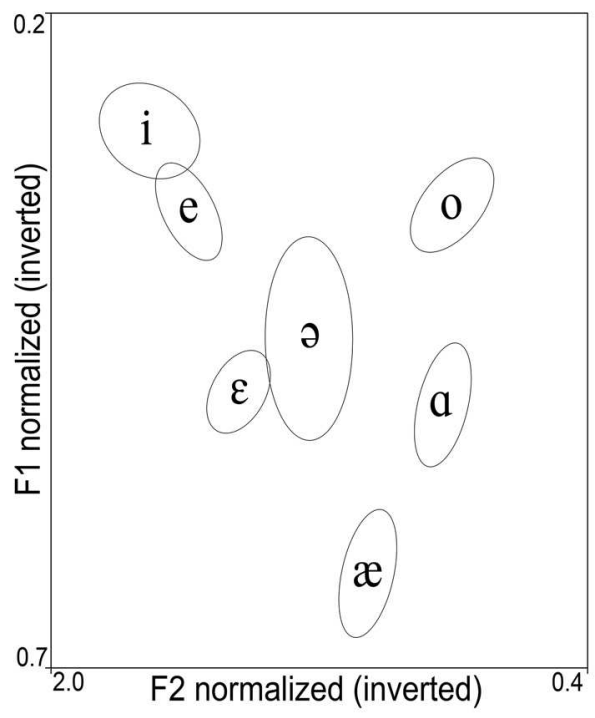

Fig. 3: Normalized vowels of speakers from Zurich

4.2 Schwa in single word utterances vs. in words in sentences

Before continuing the analyses, it is important to check whether it makes a difference whether the vowels are pronounced in words occurring in read sentences or in single words. While the corpus for Central Switzerland consists of sentences, the Zurich corpus contains both schwas in words in whole sentences as well as in single word utterances. These two are compared here. The statistical analyses in this study were done with linear mixed effects models including word and speaker as random effects using the linear mixed effects model lme4 (BATES et al. 2015) of R (R Core Team 2013), the boxplots were drawn using ggplot2 (WICKH AM 2009).

The F1 values for schwas in single word utterances are much higher than the F1 values of schwas in words spoken in a sentence. Linear mixed effects analyses prove this difference to be highly significant $\left(\chi^{2}(1)=77.16, p<.001\right)$. The $F_{2}$ and $F_{3}$ values, on the other hand, do not display any significant difference between schwas in sentences and schwas in single word utterances. Thus, when the informants only utter a single word prompted by a picture card, for example Lungä ('lung'), they articulate schwa more openly than when it appears in a word in a whole sentence, for example D Lungä isch äs Organ ('The lung is an organ').

The enunciation of a single $y$ rd into $m$ aphone in the context of a linguistic study is bound to produce hy erart 1100 (LIN BLOM 1990). The fact that in this context schwa is more open mu the ess entral ould, therefore, indicate that the speakers' target for the schwa sa a ch no quite central but which is slightly open.

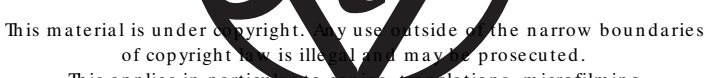

$$
\begin{aligned}
& \text { This applies in particumentans } \\
& \text { as well as storage and processing in electronic systems. }
\end{aligned}
$$




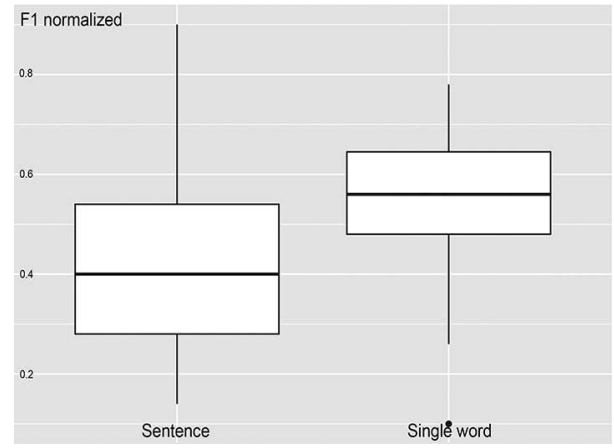

Fig. 4: Normalized F1 values of schwa in sentences vs. schwa in single words in the Zurich corpus

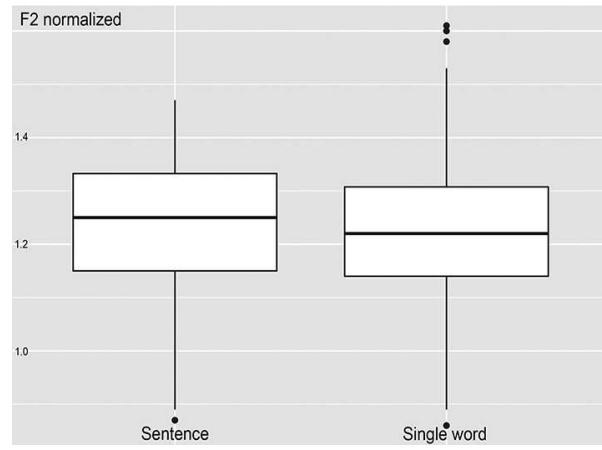

Fig. 5: Normalized F2 values of schwa in sentences vs. schwa in single words in the Zurich corpus

Due to the different quality of schwa in single word utterances, all occurrences of schwa in single words are excluded from the following analyses since the data from Central Switzerland and from Germany contains only schwas from words in sentences.

\subsection{Interdialectal variation}

Both the "Sprachatlas der deutschen Schweiz" (HOTZENKöCHeRLE 1975: volume III: map 1) and WEBER (1987: 29) state that schwa has a different quality in Central Switzerland than in most other Swiss German dialects (see section 1.2), which are here represented by Zurich German. It shall be examined here whether this can be confirmed by the present data.

First, it shall be examined whether there are differences within Central Switzerland. It must be kept in mind, however, that the sample per town is fairly small. The statistical analyses with linear mixed effects models (вАтеS et al. 2015) show that there are no significant differences between the values of the first, second and third formant between the towns in Central Switzerland. This is why it seems justified to treat the speakers from Central Switzerland as one group.

Next, the speakers from Central Switzerland are compared to the speakers from $\mathrm{Zu}$ rich. Linear mixed effects analyses revealed no differences for the $F_{1}$ and $F_{2}$ values of schwa. However, the $F_{3}$ values of the Central Swiss German speakers' schwa are significantly higher $\left(\chi^{2}(1)=14.93, \mathrm{p}<.001\right)$ than those of the Zurich German speakers, as can be seen in figure 6 .

Since low $\mathrm{F}_{3}$ values can be seen an ind atig flip rounding, the higher $\mathrm{F}_{3}$ values of Central Switzerland lead to te as mo that hese speakers pronounce schwa with more spread lips than speak om ari 1 Possi ly, this can be seen in connection with the tendency to delabia ze h vo els wo ds such as Götti > Getti ('godfather') and Füchs > Fichs ('foxes' 'D ia 


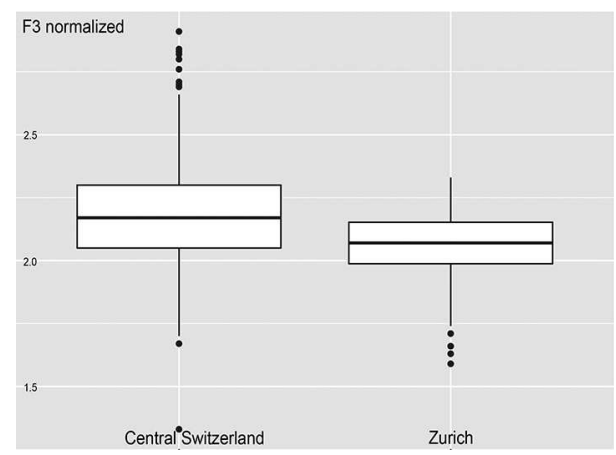

Fig. 6: Normalized $F_{3}$ values of schwa in Central Switzerland and in Zurich

Switzerland examined in the present study (HOTZEN KÖCHERLE 1962: volume I: maps 47, 52 and 101-107).

These results support the perceptual observations by HOTZENKÖCHERLE (1975: III: map 1) and WEBER (1987: 29) that there is a difference between the schwa in the dialects of Central Switzerland and Zurich. This difference, however, seems to lie less in the degree of openness or frontedness of the vowel than in the presumable pronunciation with more spread lips in Central Switzerland leading to a perceptual shift towards the unrounded vowels.

4.4 Schwa in polysyllabic content words vs. in monosyllabic function words

The map for schwa of the "Sprachatlas der deutschen Schweiz" (Hotzenkö cherLe 1975: III: map 1) in figure 1 is based on endings of infinite verbs. An analysis shall show whether the quality of the vowel which is here defined as schwa differs according to whether it occurs in a content word or a function word.

Linear mixed effects analyses show a significant effect upon both formants: Function words have significantly lower F1 values than content words $\left(\chi^{2}(1)=10.49, p=.001\right.$; see fig. 7). The F2 values are higher in function words than in content words; this difference is significant on the 0.05 level $\left(\chi^{2}(1)=6.02, p=.014\right.$; see fig. 8$)$. The schwa in content words is thus spoken with a more open and perhaps slightly less fronted quality than in function words.

A difficulty of this distinction is that several categories overlap: all content words with schwa are polysyllabic words consisting of two to four syllables while all function words taken into consideration for the present study are monosyllabic (definite or indefinite) articles. In the content word theyllable with the schwa does not carry the lexical stress. However, the conte word lik ro carry prosodic stress. The articles, on the other hand, cannot carry any dir stress if accentuation is required, articles are replaced by demonstrative prou rou

It is, of course, no coincid nce sc ra sold appear precisely in these two environments which tend to lead to lit aye and gantitative reduction of the vowel: 


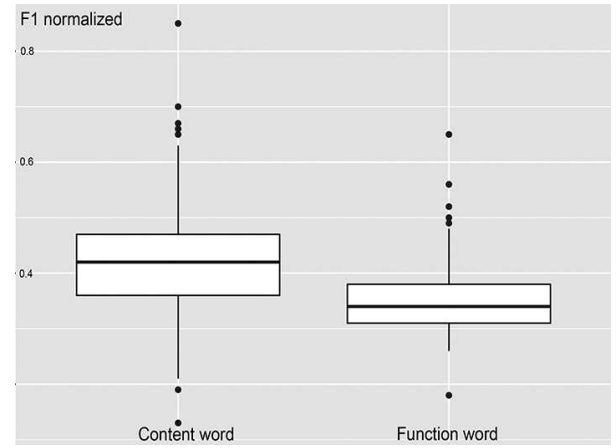

Fig. 7: Normalized F1 values of schwa in content words vs. function words

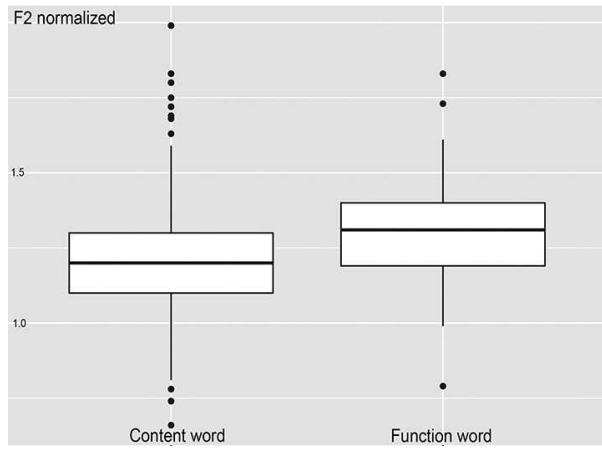

Fig. 8: Normalized F2 values of schwa in content words vs. function words

Vowels in unstressed syllables in polysyllabic words can be subject to polysyllabic shortening, which can contribute to hypoarticulation or centralization (LEHISTE 1972) and vowel quality in function words has been found to be reduced (VAN BERGEM 1993).

The present results reveal a systematic difference between the articulation of schwa in these two environments, especially in respect to its openness, in that $F_{1}$ is significantly higher in content words than in function words.

\subsection{Duration}

Phonologically, schwa is a short vowel in German. Its duration varies considerably depending on different factors, most notably its position in the phrase. In the present corpus the duration of the examined tokens of schwa varies between $19 \mathrm{~ms}$ and $189 \mathrm{~ms}$ with a mean of $66 \mathrm{~ms}$ and a median of $60 \mathrm{~ms}$.

The following analysis was done to see if there is a correlation between the duration of schwa and its formant values. In order to exclude a potentially distorting effect of prepausal vowel lengthening the tokens in which the word containing the schwa occurs at the end of a phrase or before a hesitation were excluded.

The analysis of schwa in non phrase final position reveals a significant positive correlation between the duration of schwa and its normalized F1 values; the Pearson correlation coefficient is positive and highly significant $(\mathrm{r}(515)=.356, \mathrm{p}<.001$, see fig. 9). For the normalized $\mathrm{F}_{2}$ values the correlation is slightly negative and significant on a low level $(\mathrm{r}(515)=-.096, \mathrm{p}=0.029)$.

Schwas which are pronounced longer tharefore, tend to have a more open and slightly less fronted quality than shor 1 schw $\mathrm{Ba} / \mathrm{l}$ on studies that show that a shorter duration entails a centralization if fun or or mple GENDROT/ADDA-DECKER 2005), the observation that d Ira on s ar effect 1 pon the formants leads to the assumption that the target of Sw s G an $\mathrm{nw}$ is $\mathrm{n} t$ a central but a slightly more open vowel. If the target of Swiss er s completely central vowel, one 


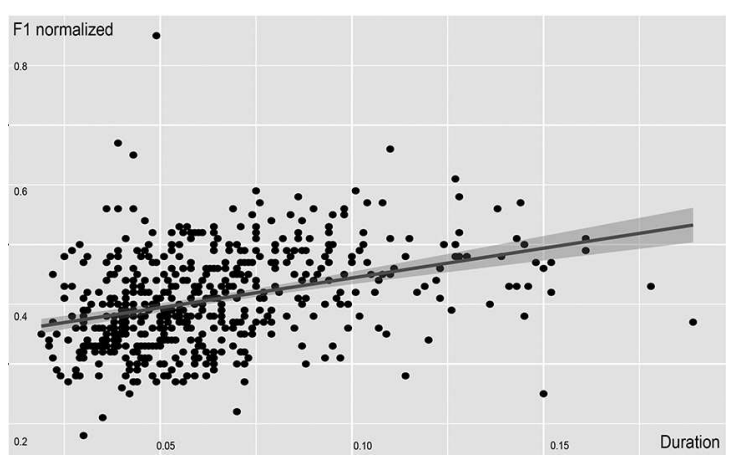

Fig. 9: Correlation of the duration of non phrase final schwa with its normalized F1 values

would expect random variation and no effect of duration (as is the case for schwa in Germany, see section 5).

4.6 Further possible internal linguistic factors

In Swiss German as well as in Standard German, schwa can occur in the word final, medial or initial position (see section 1.1). CHRISTEN et al. (2010: 187-192) find that in the Swiss variety of Standard German word final $<-\mathrm{e}>$ is pronounced with a less central quality $([\stackrel{\times}{\mathrm{e}}])$ than in the unaccented vowel in a closed final syllable such as <-en> ([ə]). Higher $\mathrm{F}_{1}$ values for schwa in word final position are also observed in American English by FLEMMING and JOHNSON (2007) and by LASS (2009). However, in the data of the present study, linear mixed effects analyses do not reveal any significant effect of the position of schwa within the word on its formants.

A further possible factor is the phonetic environment of schwa. Due to the non-representative distribution of the sounds preceding and following schwa, however, this factor was not analyzed. Different studies in other languages suggest that the phonetic environment may have a small effect upon the quality of schwa, for example KONDO (1994) for English and koopmans-VAn beinum (1992) for Dutch. In Standard German both the phonetic environment (KOHLER/RODGERS 2001: 97-123) and the geographical origin of the speaker (HAHN/SIEBENHAAR 2016) have a strong effect upon whether schwa is pronounced or elided. In French, FOUGERON, GENDROT and BÜRKI (2007) find that optional schwas differ from obligatory schwas by higher F1 values and slightly lower F2 values.

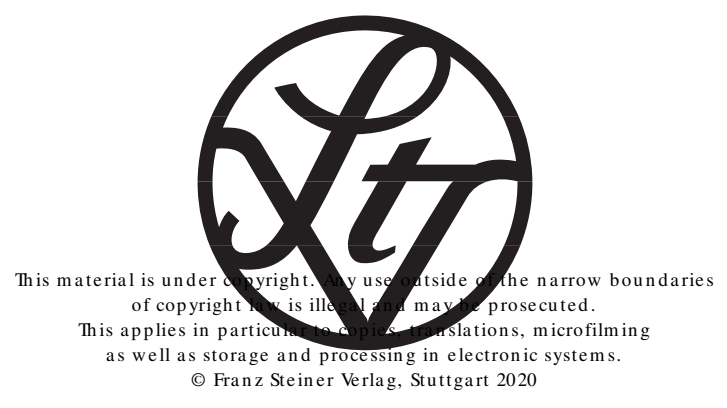




\section{Comparison with data from Germany}

As shown in section 1.2, different reference works and papers state that when looking at varieties of Standard German, schwa is spoken with a more central quality in Central and Northern Germany as opposed to a more open quality in Southern Germany, Austria and Switzerland. Though the Swiss variety examined here is not the standard variety but the dialect of the specific region, it will still be interesting to see whether this effect can be confirmed. In this section Swiss German is compared to Standard German by two speakers from Germany.

The data of the speakers from Germany is from the "Kiel Corpus of Read Speech" (KOHLER/PÄTZOLD/SIMPSON 1997, SIMPSON 1998, Database "kielread”). It contains segmented audio data by a 35 year old male speaker from Rhineland-Palatinate and a 50 year old female speaker from Lower Saxony who each read 100 sentences in Standard German, amounting to 283 tokens for schwa and 614 tokens for other vowels. The same values were measured and extracted as for the data from Switzerland. The absolute formant values (before the normalization) of these two speakers are typical for the "Kiel Corpus of Read Speech" (PÄTZOLD/SIMPSON 1997).

The figures 10 to 12 show that both in the Swiss dialects as well as in Standard German schwa is clearly a central vowel.

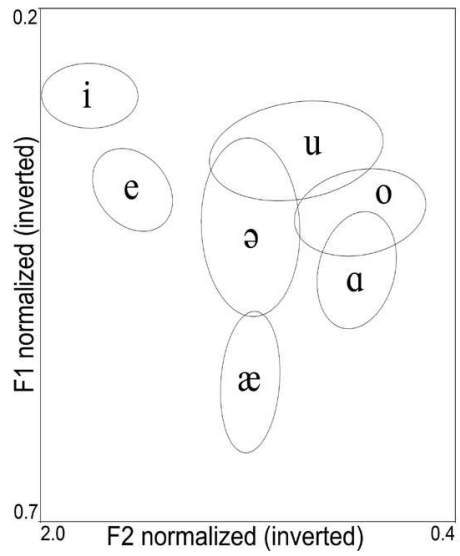

Fig. 10: Normalized vowels of speakers from Central Switzerland (same as fig. 2)

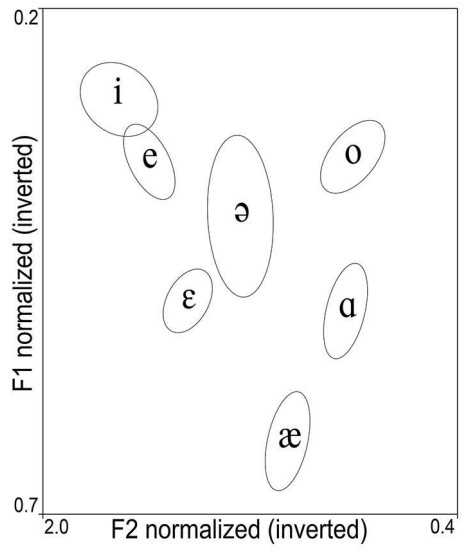

Fig. 11: Normalized vowels of speakers from Zurich (without single word utterances)

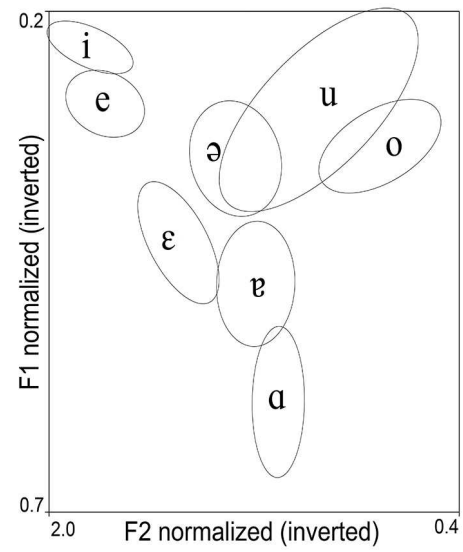

Fig. 12: Normalized vowels of speakers from Germany

First, the pronunciation of schwa in $t^{t}$ three arie $\mathrm{f}$ is examined. The normalized $\mathrm{F}_{1}$, $\mathrm{F}_{2}$ and $\mathrm{F}_{3}$ values are compared for the $\mathrm{S}_{\text {arc }}$ rom entral Switzerland, Zurich and Germany. As above, only the data ro se enc lwas un for the following analyses. 


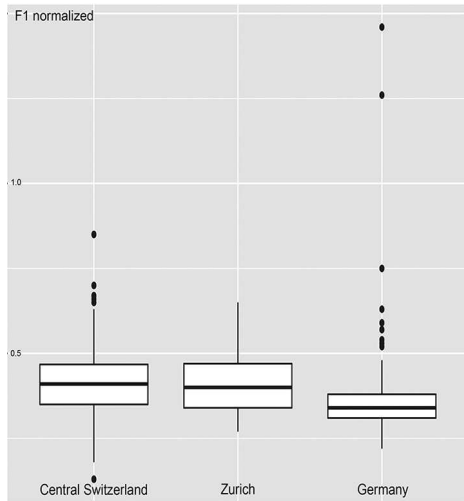

Fig. 13: Comparison of the normalized $F_{1}$ values of the speakers from Central Switzerland, Zurich and Germany

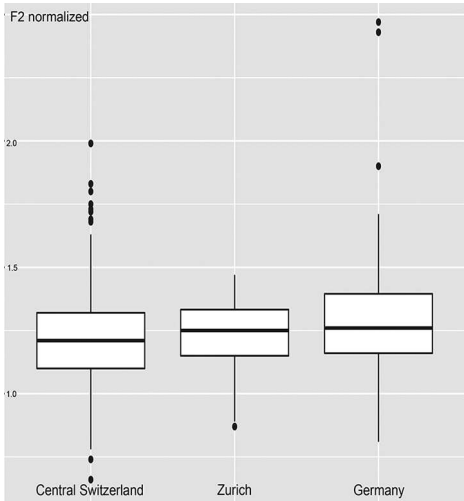

Fig. 14: Comparison of the normalized $\mathrm{F}_{2}$ values of the speakers from Central Switzerland, Zurich and Germany

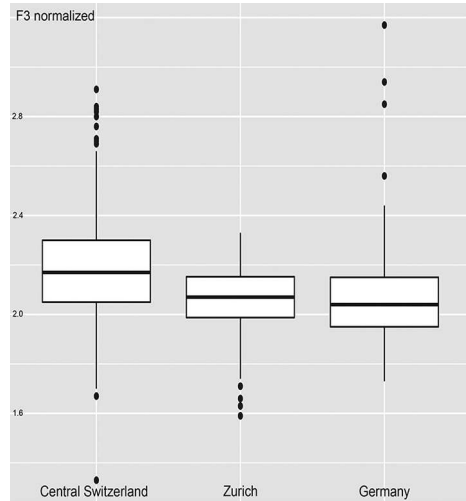

Fig. 15: Comparison of the normalized $\mathrm{F}_{3}$ values of the speakers from Central Switzerland, Zurich and Germany

While there is no significant difference between the first two formants of schwa in the dialects of Central Switzerland and of Zurich (see section 4.3), when comparing the Swiss data to the data from the speakers from Germany, linear mixed effects analyses show that the $F_{1}$ values are significantly lower for the speakers from Germany $\left(\chi^{2}(1)=6.01\right.$, $\mathrm{p}=.014)$. If these speakers are indeed representative of their area, it can be presumed that the speakers of Swiss German pronounce schwa as a more open vowel than the German speakers of Standard German. The pronunciation of schwa thus seems to be more open in German-speaking Switzerland, both in the dialects and - based on the literature referred to in section $\mathbf{1 . 2}$ - in the standard variety, in comparison to Central and Northern Germany.

In order to interpret the data for schwa it makes sense to take into consideration the vowel systems of the three varieties. The normalized $\mathrm{F}_{1}$ and $\mathrm{F}_{2}$ values of every region are plotted in the figures 10-12. The observation that in Standard German schwa is fairly closed is most likely due to the existence of the vowel $/ \mathfrak{r} /$. In Standard German, there is a contrast between $/ \mathfrak{b} /$ and $/ \supset /$ in word pairs such as leiser ['laeze] ('quieter') vs. leise ['laęza] ('quiet'). A more open pronunciation of schwa would endanger this distinction. By contrast, there is no such vowel in the Swiss German dialects of Central Switzerland and of Zurich, thus nothing stands in the way of more open pronunciation variants of schwa.

As reported in section 4.3, the values of $\mathrm{F}_{3}$ are higher for the speakers from Central Switzerland than for the speakers from Zwich. Linear mixed effects analyses show that the $F_{3}$ values of the speakers fron Germa ar milar to the $F_{3}$ values of the speakers from Zurich and also significan $1 y$ lon the seakers from Central Switzerland $\left(\chi^{2}(1)=5.54, \mathrm{p}=.019\right)$

An analysis of the effect o dur non hon e final schwa upon its quality revealed no significant correlatio In th st the s eakers of Swiss German, who pro- 
nounce "long" schwa with a more open and slightly less fronted quality, the speakers from Germany do not pronounce schwa with a different vowel quality if it is longer. Furthermore, there is no significant difference between the quality of schwa in content words or in function words in the data from Germany.

\section{Discussion}

The analyses of the formant values of schwa in the Swiss German dialects of Central Switzerland and Zurich reveal higher $\mathrm{F}_{1}$ values for schwa suggesting a more open pronunciation in the following cases:

- in hyperarticulated speech in single words (in comparison to read sentences),

- in content words (in comparison to function words) and

- when its duration is longer.

If the target for schwa in Swiss German were a completely central vowel there could be no phonetic undershoot or hypoarticulation (see LINDBLOM 1990). It would be expected that factors such as the above-mentioned have no effect and that the phonetic variation would be random. The fact that certain factors trigger a more open pronunciation of schwa indicates that the target of the Swiss German schwa is a vowel which is not quite central. Since less careful and shorter articulation are known to cause a more central pronunciation of full vowels, it can be assumed that the target of schwa is closer to the slightly open central vowel pronounced when the articulation is more deliberate.

This assumption is reinforced by the comparison to the data from Germany, where the schwa is presumed to be a vowel whose position is quite central. The analysis of the formant values of the read speech by the speakers of Standard German reveals that neither the duration nor the word class has an effect upon the formant values of schwa. The fact that the variation shows no pattern, i.e. the factors which are known to cause centralization have no effect, indicates that in Germany - in contrast to Switzerland the position of schwa's target is fairly central.

The observation that the target for the Swiss German schwa is a slightly open vowel can also be illustrated by an example from the recordings: When a speaker from Zurich is shown the picture of a ladle she first says Löffäl ('spoon') but then realizes that the correct word is Chelä ('ladle'), which she then mumbles before enunciating it clearly for the recording. She thus says ['løf:3l $\{p$ D: 'xelə $p\}$ 'xel3]. In Löffäl and even more so the second time she utters the word Chelä she pronounces the schwa with a noticeably more open quality than in the mumbled uttanance of Chelä.

An interdialectal comparison rey als sign cap differences between the values of the third formant of schwa in Cent al St er an an in Zurich German (see fig. 6), indicating that in Central Switzer $m$ sch $A$ is lonoun ed with more spread lips than in Zurich. This makes the vowel p rcep cly ose 6 th (spread) vowel $[x]-$ a difference which has been perceived and ed at dial ctological literature. 
The comparison with the speakers from Germany shows that in the Swiss dialects schwa is pronounced with a more open quality than in the Standard German varieties of Central and Northern Germany. A reason for the more closed pronunciation of schwa in Standard German may lie in the aim to avoid an overlap with the vowel / $\mathrm{e} /$.

That the schwa's target in Swiss German is a less central vowel than the schwa in the Standard German variety of Central and Northern Germany may also be one factor which explains the tendency of many Swiss to represent this sound with the letter <ä>, thus expressing that it is perceived as closer to $[æ]$ or $[\varepsilon]$ (both generally transliterated as $<\ddot{a}>$ ) than to the Standard German [ə]. Nevertheless, the analyses of the formants reveal that the allophones of /a/ in Swiss German are central and not open or front vowels. The phonetic symbol which represents them best is [3].

\section{Acknowledgments}

This study was carried out within the research project "Ländere" (CHRISTEN/BUCHELI/GUNTERN 2015), which was directed by Prof. H. CHRISTEN of the University of Fribourg, Switzerland, and which was funded by the Swiss National Science Foundation (grant number 140287). Special thanks go to HANNA RUCH for providing the Zurich German corpus and for her help with the statistical analyses as well as to the research team of the "Ländere" ${ }^{\mathrm{n}}$ project, namely HELEN CHRISTEN, MARINA PETKOVA, ALEXANDRA SCHIESSER, DIETER STUDER and PASCALE SCHALLER for their support and their helpful comments.

\section{References}

ADANK, PATTI / ROEL SMITS / ROELAND VAN HOUT (2004): A comparison of vowel normalization procedures for language variation research. In: The Journal of the Acoustical Society of America 116 (5), 3099-3107.

AUER, PETER (2014): Anmerkungen zum Salienzbegriff in der Soziolinguistik. In: Linguistik online 66 (4), doi:10.13092/lo.66.1569.

BATES, DOUglas / MARTIN MÄCHLER / Ben Bolker / SteVe WALKer (2015): Fitting Linear Mixed-Effects Models Using lme4. In: Journal of Statistical Software 67 (1), 1-48.

BIEBERSTEDT, ANDREAS / JÜRGEN RUGE / INGRID SCHRÖDER (2016): Hamburger Variablenkatalog. Katalog sprachlicher Variablen zur Dialektalitätsmessung. In: BIEBERSTEDT, ANDREAS / JÜRGEN RUGE / INGRID SCHRÖDER (ed.): Hamburgisch. Struktur, Gebrauch, Wahrnehmung der Regionalsprache im urbanen Raum. Frankfurt a. M.: Lang, 387-420.

Boersma, PAUl / DAVID WEENINK (2015): Praat: doing phonetics by computer (version 6.0.08). <http://www.praat.org>, accessed 5 Decamber 2015.

BÜRKLE, MiChAel (1995): Zur Aussy ache de Jost eichischen Standarddeutschen. Die unbetonten Silben. Frankfurt a. M.: I ng chr en $\mathrm{dr}$ de tschen Sprache in Österreich. 17).

CHRISTEN, Helen (2004): Diale Schrey ruoder sorr ech hassä Text schribä. In: GLASER, ELVIRA / PETER OTT / RUDO F S HV RZ
Wiesbaden: Steiner, 71-86. 
CHRISTEN, Helen (2015): Die Dialektologie und ihre (neuen) Räume. In: EICHINGER, LUDWIG (ed.): Sprachwissenschaft im Fokus. Positionsbestimmungen und Perspektiven. Berlin: de Gruyter (Jahrbuch des Instituts für deutsche Sprache 2014), 353-378.

CHRISTEN, HELEN / NADJA BUCHELI / MANUELA GUNTERN (2015): Ländere ${ }^{n}$ : Die Urschweiz als Sprach(wissens)raum. In: KEHREIN, ROLAND / ALFRED LAMELI / STEFAN RABANUS (ed.): Regionale Variation des Deutschen. Projekte und Perspektiven. Berlin: De Gruyter, 619-641.

CHRISTEN, HELEN / MANUELA GUNTERN / INGRID HOVE / MARINA PETKOVA (2010): Hochdeutsch in aller Munde. Eine empirische Untersuchung zur gesprochenen Standardsprache in der Deutschschweiz. Stuttgart: Steiner (Zeitschrift für Dialektologie und Linguistik. Beihefte. 140).

CRYSTAL, DAVID (2008): Txtng. The Gr 8 Db8. New York: Oxford University Press.

Database "kielread". <http://www.phonetik.uni-muenchen.de/ jmh/research/pascwebsite/Draft_ Harrington_pasc_databases.html>, accessed 14 June 2015.

elmentaler, Michael / Peter Rosenberg (2015): Norddeutscher Sprachatlas (NOSA). Band 1: Regiolektale Sprachlagen. Hildesheim: Olms (Deutsche Dialektgeographie. 113.1).

FERGUSON, CHARLES (1959): Diglossia. In: Word 15, 325-340.

FLEISCHER, JÜRG / STEPHAN SCHMID (2006): Zurich German. In: Journal of the International Phonetic Association 36 (2), 243-255. doi:10.1017/Soo25100306002441.

FLEMMING, EDWARD / STEPHANIE JOHNSON (2007): Rosa's roses: reduced vowels in American English. In: Journal of the International Phonetic Association 37 (1), 83-96. doi:10.1017/ So025100306002817.

FLYNN, NICHOLAS (2011): Comparing vowel formant normalisation procedures. In: York Papers in Linguistics Series 2 (11), 1-28.

FOUGERON, CÉCILE / CÉDRIC GENDROT / AUDREY BÜRKI (2007): On the acoustic characteristics of French schwa. In: Proceedings of ICPhS XVI, Saarbrücken, 941-944.

GENDROT, CÉDRIC / MARTINE ADDA-DECKER (2005): Impact of duration on $\mathrm{F}_{1} / \mathrm{F}_{2}$ formant values of oral vowels: an automatic analysis of large broadcast news corpora in French and German. In: Interspeech 2005 - Eurospeech, 9 th European Conference on Speech Communication and Technology, Lisbon, Portugal, September 4-8, 2453-2456.

GRANT, TIM (2013): TXT 4N6: method, consistency, and distinctiveness in the analysis of sms text messages. In: Journal of Law and Policy 21 (2), 467-494.

HAAS, WALter (1978): Sprachwandel und Sprachgeographie. Wiesbaden: Steiner (Zeitschrift für Dialektologie und Linguistik. Beihefte. 30 ).

hahn, Matthias / Beat SiebenhaAR (2016): Sprechtempo und Reduktion im Deutschen (SpuRD). In: JOKISCH, OLIVER (ed.): Elektronische Sprachsignalverarbeitung. Dresden: TUDpress (Studientexte zur Sprachkommunikation. 81), 198-205.

HOTZENKÖCHERLE, RUDOLF (ed.) (1962-1997): Sprachatlas der deutschen Schweiz. Bern/Basel: Francke.

HOVE, INGRID (2002): Die Aussprache der Standardsprache in der deutschen Schweiz. Tübingen: Niemeyer.

KISLER, THOMAS / FLORIAN SCHIEL / HAN SLOETJES (2012): Signal processing via web services: the use case WebMAUS. In: Proceedings Digital Humanities 2012, 30-34.

KLEINeR, STEFAN / RALF KNÖBL / MAX MANGOld (2015): Duden - Das Aussprachewörterbuch. 7., komplett überarbeitete und aktualisierte Auflage. Berlin: Dudenverlag (Duden. 6).

KOHLER, KLAUS J. / MATTHIAS PÄTZOLD / AR SIMPSON (1997): From the acoustic data collection to a labelled speech data bo of spo and dard German. In: SIMPSON, ADRIAN P. / KLAUS J. KOHLER / TOBIAS RY ITS LT Ed. The Kiel Corpus of Read/Spontaneous Speech - Acoustic data base, proce $\mathrm{g}$ too and analysis sults. Kiel: IPDS (Arbeitsberichte des Instituts für Phonetik und dig tale pr hv er Universität Kiel (AIPUK). 32), $1-29$. 
KOHLER, KLAUS / JONATHAN RODGERS (2001): Schwa deletion in German read and spontaneous speech. In: Arbeitsberichte des Instituts für Phonetik und digitale Sprachverarbeitung der Universität Kiel (AIPUK. 35), 97-123.

KONDO, YUKO (1994): Targetless schwa: is that how we get the impression of stress-timing in English? In: Proceedings of the Edinburgh Linguistic Department Conference 94, 63-76.

KOOPMANS-VAN BEINUM, FLORIEN (1992): What's in a schwa? In: Institute of Phonetic Sciences, University of Amsterdam, Proceedings 16, 53-64.

KRECH, EVA-MARIA / EBERHARD STOCK / URSULA HIRSCHFELD / LUTZ CHRISTIAN ANDERS (2009): Deutsches Aussprachewörterbuch. Berlin: De Gruyter.

LAMELI, ALFRED (2004): Standard und Substandard. Regionalismen im diachronen Längsschnitt. Stuttgart: Steiner (Zeitschrift für Dialektologie und Linguistik. Beihefte. 135).

LASS, ROGER (2009): On schwa: synchronic prelude and historical fugue. In: MINKOVA, DONKA (ed.): Phonological weakness in English: from old to present-day English. Houndmills: Palgrave Macmillan, 47-77.

LEHISTE, ILSE (1972): The Timing of Utterances and Linguistic Boundaries. In: Journal of the Acoustical Society of America 51, 2018-2024.

LENZ, ALEXANDra (2010): Zum Salienzbegriff und zum Nachweis salienter Merkmale. In: ANDers, Christina / Markus hundt / Alexander lasch (ed.): Perceptual Dialectology: Neue Wege der Dialektologie. Berlin: De Gruyter, 89-110.

LINDBLOM, BJÖRN (1990): Explaining phonetic variation: A sketch of the $\mathrm{H} \& \mathrm{H}$ theory. In: hardcastle, william J. / Alain marchal (ed.): Speech Production and Speech Modeling. Dordrecht: Kluwer Academic Publishers, 403-439.

moosmüller, sylvia (2007): Vowels in Standard Austrian German. An Acoustic-Phonetic and Phonological Analysis. [Habilitationsschrift, Universität Wien]. <https://www.kfs.oeaw.ac.at/ publications/habil_2007may28_tableofcontents_zus_final.pdf >, accessed 13 August 2018.

NeARey, Terrance M. (1977): Phonetic Feature Systems for Vowels. Dissertation, University of Alberta. Reprinted 1978 by the Indiana University Linguistics Club.

NIEDERBERGER, ERNST (2007): Nidwaldner Mundart. 3. Auflage. Dallenwil: Edition Odermatt. NOSKE, ROLAND (1992): A Theory of Syllabification and Segmental Alternation. With studies on the phonology of French, German, Tonkawa and Yawelmani. [Doctoral Thesis, Tilburg University]. <http://rnoske.home.xs4all.nl/CV/publicaties/proefschrift>, accessed 22 April 2018. PÄTZOLD, MATTHIAS / ADRIAN P. SIMPSON (1997): Acoustic analysis of German vowels in the Kiel Corpus of Read Speech. In: SIMPSON, ADRIAN P. / KLAUS J. KOHLER / TOBIAS RETTSTADT (ed.): The Kiel Corpus of Read/Spontaneous Speech - Acoustic data base, processing tools and analysis results. Kiel: IPDS (Arbeitsberichte des Instituts für Phonetik und digitale Sprachverarbeitung der Universität Kiel (AIPUK). 32), 215-247.

PetKova, MARINA (2017): Linguistic landscapes in der Innerschweiz: Dialekt, Toponyme und heraldische Zeichen als Ausdruck von Raumzugehörigkeit. In: HUNDT, MARKUS / CHRISTOPH PURSCHKE / EVELYN ZIEGLER (ed.): Sektionsband zum IGDD-Kongress 2015, Linguistik online $85(6)$. <https://bop.unibe.ch/linguistik-online/article/view/4085>, accessed 30 August 2018.

R Core Team (2013): R: A language and environment for statistical computing. R Foundation for Statistical Computing, Vienna, Austria. <http://www.R-project.org/>, accessed 17 October 2019.

RUCH, HANNA (2015): Vowel convergence 1. The Scottish Consortium for ICPb 2015 (ef $: \mathrm{P}$ peedings of the 18th International Congress of Phonetic Sciences. Glasgow: Jniv sity $\mathrm{G}^{\prime}$ sgon Paper 0404.

SCHMid, STEPHAN (2004): Zur lquar aat inder M ndart der Stadt Zürich. In: Linguistik online $20,93-116$. 
SCHMIDT, JÜRGEN E. / JOACHIM HERRGEN (2001 ff.): Digitaler Wenker-Atlas. Erste und vollständige Publikation von Georg Wenkers "Sprachatlas des Deutschen Reichs". 1888-1923. Marburg: Forschungsinstitut für deutsche Sprache "Deutscher Sprachatlas".

SIEBENHAAR, BEAT (2006): Das sprachliche Normenverständnis in mundartlichen Chaträumen der Schweiz. In: ANDROUTSOPOUlos, JANNIS / JENS RUKEHL / PETER SCHLOBINSKI / TORSTEN SIEVER (ed.): Neuere Entwicklungen in der linguistischen Internetforschung. Hildesheim: Olms (Germanistische Linguistik. 186-187), 45-67.

SIMPSON, ADRIAN P. (1998): Phonetische Datenbanken des Deutschen in der empirischen Sprachforschung und der phonologischen Theoriebildung. Kiel: IPDS (Arbeitsberichte des Instituts für Phonetik und digitale Sprachverarbeitung der Universität Kiel (AIPUK). 33).

sokolowsKY, KAY (2012): Bored beyond belief (4): Mein Wappenbier. <http://www.kaysokolo wsky.de/bored-beyond-belief-4-mein-wappenbier>, accessed ${ }_{13}$ October 2019.

Staffeldt, SVen (2010): Zum Phonemstatus von Schwa im Deutschen. Eine Bestandsaufnahme. In: Studia Germanistica 7, 83-96.

STARK, ELISABETH / SIMONE UEBERWASSER / Beni RUeF (2009-2014): Swiss SMS Corpus. University of Zurich. <https://sms.linguistik.uzh.ch>, accessed 1 March 2016.

THOMAS, ERIK R. / TYLER KENDALL (2007): NORM: The vowel normalization and plotting suite (version 1.1). <http://lingtools.uoregon.edu/norm>, accessed 13 August 2015.

VAN BERGEM, DICK R. (1993): Acoustic vowel reduction as a function of sentence accent, word stress, and word class. In: Speech communication 12 (1), 1-23.

WEBER, ALbert (1987): Zürichdeutsche Grammatik. Ein Wegweiser zur guten Mundart. 3. Auflage. Zürich: Rohr (Grammatiken und Wörterbücher des Schweizerdeutschen in allgemeinverständlicher Darstellung. 1).

WebMAUS: Automatic Segmentation and Labelling of Speech Signals over the Web. 2015. $<$ https://clarin.phonetik.uni-muenchen.de/BASWebServices/\#/services/WebMAUSBasic>, accessed 2 June 2015 .

WICKHAM, HADLEY (2009): ggplot2: Elegant Graphics for Data Analysis. New York: Springer.

WIESE, RICHARD (1986): Schwa and the structure of words in German. In: Linguistics 24 (4), 697-724.

WRD (2010): Dittsche - Das wirklich wahre Leben. Staffel 9: Biddä! <https://www1.wdr.de/fern sehen/dittsche>, accessed ${ }_{13}$ October 2019.

\section{DR. INGRID HOVE}

University of Fribourg, Departement für Germanistik, Av. de l'Europe 20, CH-1700 Fribourg, Switzerland and University of Zurich, Phonetics lab, Rämistr. 71, CH-8006 Zurich

E-mail address: <ingrid.hove@unifr.ch>

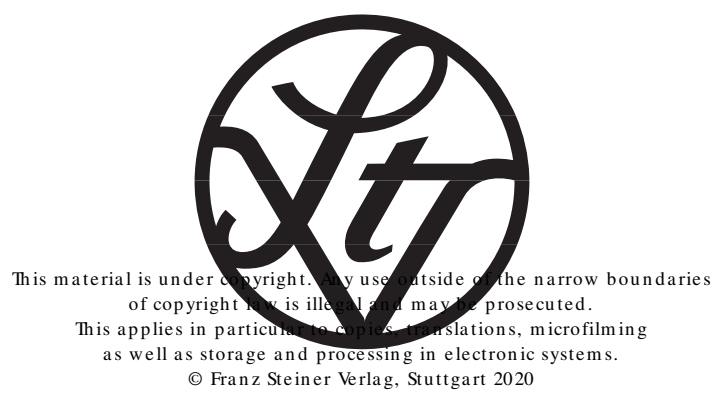

